\title{
A STRATEGIC MODEL OF SUSTAINABLE MOBILITY IN THE CITY OF ZAGREB AND ITS SURROUNDING AREA
}

\author{
Jasna Blašković Zavada ${ }^{1}$, Borna Abramović ${ }^{2}$ Denis Šipuš \\ 1,2,3 University of Zagreb, Faculty of Transport and Traffic Sciences, Zagreb, Croatia
}

Received 8 September 2017; accepted 20 October 2017

\begin{abstract}
The European Union is trying to strengthen economic, social, and territorial cohesion of certain regions in order to improve the quality of life for its residents. The key part of that process is improving the urban and regional mobility, which is essential for a modern living standard of the residents in those areas. This paper discusses the attitudes and documents of the EU that encourage sustainable urban and regional mobility through the development and use of public transport networks as a part of the regional, urban and suburban transport in larger cities. Special emphasis is placed on Master plans for transport development in cities, counties and functional regions, which serve as initial and strategic points for launching further transport projects. Co-funding of the design documentation of the Master plans is encouraged, as well as carrying out projects of sustainable urban and regional mobility through EU operational programmes. A case of an integrated passenger transport system and shipping tariff in the City of Zagreb, Zagreb county, and Krapina-Zagorje county was analysed.
\end{abstract}

Keywords: EU's cohesion policy, urban and regional mobility, Master plan, integrated passenger transport, transport projects.

\section{Introduction}

The cohesion policy of the EU for the period 2014-2020 lists urban and regional mobility as one of the key challenges for European cities and functional urban areas. Emphasis is on the importance of integrated strategies and cooperation in a functional regional context. The key factor in the process of harmonisation of the urban and suburban development is an integrated urban-suburban transport with emphasis on sustainable mobility.

The Transport Development Strategy of the Republic of Croatia for 2014-2030 (Ministry of the Sea, Transport and Infrastructure,
2017) encourages developing a Master plan of traffic development and mobility which would act as a starting document for further transport projects. One of the main priorities of the urban, suburban and regional mobility sector is introducing integrated transport systems in larger cities and their suburbs, and/or regional areas.

The railway systems in the model of integrated transport and shipping tariff in the City of Zagreb, Zagreb county and Krapina-Zagorje county should take on the traffic load.

Authors in their paper (Šimecki et al. 2013) stress the need for a regional connectivity

${ }^{1}$ Corresponding author: jblaskovic@fpz.hr 
between transport networks which would improve the social and economic status of the connected regions. The issue of limited transport accessibility in certain regions brings about the lack of development and even causes potential emigration. In their paper, (Zitricky et al., 2015) pointed out to the problem the difference in views of the quality of transport service in regional passenger transport between the users and the operators. The main setbacks in the improvement of quality are evident in the vehicles and infrastructure. (Gašparik et al., 2015) proposed in their research a methodology of quality assessment in regional passenger transport. They stress that its applicability is possible when comparing integrated transport systems based on the levels of service quality. In their work (Stopka, et al., 2015) showed a subjective evaluation of customer satisfaction with the transport service in the integrated lines, compared to the nonintegrated ones. (Van de Vijver et al., 2016) research scrutinizes the mutual and complex causal relationship between air passenger transport and regional development in the European NUTS2-regions. (Torok, 2016) researched the journey times in the region, for example, in Budapest, and improved the method of temporal-spatial visualisation that can be used in analysis of regional transport systems. (Stoilova and Nikolova, 2016) outlined a methodology for classifying railway passenger terminals, claiming that the method can be used for all terminals and stations in railway transport.

\section{Urban and Regional Mobility in the Context of Strengthening Territorial Cohesion}

By carrying out its cohesion policy, the European Union is aiming to achieve the objectives set by the economic, social, and territorial cohesion. The urban and regional mobility plays an important role within the EU's cohesion policy, particularly with regard to the territorial cohesion. Certain integrated strategies are stimulated that would expedite sustainable development and strengthen the city's transport resistance.

Territorial Agenda of the European Union 2020 (European Commission, 2011) encourages cooperation and networking of cities, and long-term smart development of urban regions that look beyond administrative borders. Integrated urban development directs cities towards their functional urban areas and their surrounding rural spaces creating urban-rural connections. Advantage should be given to functional regions, and developmental processes should be analysed regardless of the administrative-territorial borders. This initiative poses a great challenge for cities and regions, and requires a multidisciplinary approach and cooperation of all parties.

Transport infrastructure should support a balanced regional development and should mutual supplementation of rural and urban areas. It is necessary to develop an integrated approach and ensure mobility and equal accessibility in all areas, which would create the conditions for economic growth, but also social integration as an important element of social quality and justice.

EU Cohesion Policy for 2014-2020 (European Commission, 2014) lists cities as catalysts for development, innovation, and creativity, places that gather developmental potentials and challenges.

Promoting a model of polycentric and balanced territorial development aims to 
avoid polarization between the capital city, metropolitan areas and mid-size cities. The priority is given to efficiency and density of secondary transport infrastructure networks for an integration of regional and urban economies, as well as strengthening midsize and small-size cities when generating regional development. Mid-size and small cities should play a key role on a regional level with transport accessibility the prerequisite of their development. The development and use of public transport networks in the function of regional, urban, and suburban traffic should be encouraged. (Croatian Chamber of Economy, 2015)

Intermodality, that is, integrated systems of public transport and their development is strongly supported by the White paper presented by European Commission (2011). White paper on transport, a strategic document for the development of the EU, suggests the possibility of introducing obligatory Mobility plans for cities of a certain size, according to national standards based on EU directives. (European Commission, 2011)

The general objective of the transport development of the Republic of Croatia is a balanced and sustainable transport system based on the principles of territorial cohesion. Developing regional spatial features ensures a balanced spatial, regional, and rural progress and ensures the conditions for a quality life in the entire state territory. A key factor of the balanced urban and suburban development is an integrated urban-suburban transport with emphasis on sustainable mobility.

The Transport Development Strategy of the Republic of Croatia for 2014-2030 (Ministry of the Sea, Transport and Infrastructure,
2017) encourages cooperation in the functional regional context by means of defining five functional regions:

- Central Croatia;

- Eastern Croatia;

- Northern Adriatic;

- Northern and Central Dalmatia, and

- South Dalmatia.

Functional regions are defined based on the transport interaction analysis regardless of their administrative borders. Initially, however, they were defined based on the key characteristics of the regions. After the National Traffic Model has been designed, a more detailed scope of each functional region will be available.

\section{Master Plan of Transport Development/ Mobility - Requirement for EU Financing of Urban and Regional Mobility Projects}

Master plans of transport development for cities, counties and regions represent the starting and strategic documents for further development of transport projects. They act as a bridge between Transport Development Strategy and projects themselves. As underlying foundations, problems and opportunities for improving the transport system of cities and regions should be identified, and set the frameworks for potential solutions. The regional strategic documents are groundwork for designing transport projects and their EU funding.

Master plans should place special emphasis on solutions to connecting the public transport of cities and municipalities within a county, stress the possibility of mutual connectivity of the counties and border areas with neighbouring countries. It should focus on the needs of the residents in their 
daily commutes so that through projects of integrated transport, their transport becomes more accessible, faster, and cheaper. Master plans of mobility, apart from defining infrastructure investments, will ensure a development of transport projects that will make it possible to implement common tariffs and transport tickets for an easier purchase. (Ministry of the Sea, Transport and Infrastructure, 2015)

A design of the Master plan should be preceded by a concept of a transport model that should be interoperable with the National Transport Model. The transport model is a computer simulation of the movement of people and goods in a transport network within the framework of a defined spatial part of the Plan (functional region/ several counties). It comprises a database of the existing state and serves as basis for planning and financial justification of investments into the transport system. Upon completion of the Master plan, the transport model should test the identified measures. The Plan would thereby be confirmed as the all-encompassing plan of a functional region/several counties.

The designed Master plan of transport development should, as a developmental document, be in accordance with the other developmental plans. It is the basic document for designing spatial plans of a new generation based on the principles of integrated approach in spatial planning, which goes beyond administrative and territorial borders, improving the accessibility to cities and isolated areas and strengthening territorial cohesion.

Pursuant to Environmental Protection Act, all strategies, programmes and plans financed by the EU are subject to
Strategic Environmental Assessment (SEA) (Official Gazette of the Republic of Croatia, 2015). Master plans, as regional strategic documents in the transport sector, are required to conduct the Strategic Environmental Assessment. Therefore, likely significant impacts on the environment that might affect the implementation of the Master plan should be identified and measures that might alleviate those impacts should be proposed.

\subsection{Transport Development Strategy of the Republic of Croatia for 2014-2030 - National Strategy}

The Transport Development Strategy of the Republic of Croatia for 2014-2030 (Ministry of the Sea, Transport and Infrastructure, 2017) (hereinafter: Strategy) is a strategic document that represents the fundamental reform of the transport policy of the Republic of Croatia for the next 15 years, comprising six strategic multimodal goals, 28 special multimodal goals, and 180 sector measures for achieving the objectives set by the Strategy.

Adopting the Transport Development Strategy of the Republic of Croatia for 2014-2030 (Ministry of the Sea, Transport and Infrastructure, 2017) completes the first phase of the design of the Strategy. Drafting the second stage of the Strategy is currently in progress, with emphasis on strategic assessment of the environmental impact for 2017-2030, which will become a complete national strategic document based on the all-encompassing transport data and national traffic model. For the first time, the Strategy lists "Urban, sub-urban and regional mobility" as a separate sector that defines 22 measures (U.1-U.22) related to operability, organisation, and infrastructure. 
The introduction of the new sector into the strategic document on a national level ensured the co-financing of the design of the Master plan of transport development and the preparation of project for a certain functional region/several counties.

Within certain sectors, the measure U.22 "Review/update local/regional transport master plans" was implemented as a priority sector measure. The measure introduces the required transport planning on completely new grounds, taking into consideration not only the infrastructure, but also the operative and organisational aspects. Functional regions and/or cities will be required to develop their own Master plans, that is, plans of sustainable urban mobility that are crucial for an investment into public transport systems.

The main priorities of the sector of public urban, suburban, and regional mobility focus on the following:

- Establishing integrated transport systems in the main cities and their suburban and/or regional areas;

- Developing measures to increase the share of public transport and means of PT and zero emission modes, such as $P \& R$, restriction to private traffic in the centres of the cities, prioritisation for public transport through ITS systems, etc.; and

- Increasing the sustainability of the system by performing a reorganisation of the sector, in the organisational and legislative sense, particularly by introducing public service contracts in line with the regulation (EC) No. $1370 / 2007$, improving the efficiency of the maintenance, reducing the environmental impact, and implementing measures to increase the safety of the system.

\subsection{EU Funding of the Urban and Regional Mobility in the Republic of Croatia}

The fundamental documents for financing urban and regional mobility in the Republic of Croatia by the EU funds are the Operational Programmes "Transport" for 2017-2013 (funding ensured up to 2016) and "Competitiveness and Cohesion" for 2014-2020. The operational programmes are documents that define the priority areas (so-called priority axes) for EU funding. (Ministry of the Sea, Transport and Infrastructure, 2015)

“Transport” ensures co-funding of projects in urban and regional mobility, namely, designing strategic documents (Master plans), economic and technological, and technological documentation, environmental documentation and other studies and elaborates, the design of which is required to co-finance the launch of the projects through the Operational programme "Competitiveness and Cohesion".

Within the thematic objective 07 of the Operational Programme "Competitiveness and Cohesion" - Promoting sustainable transport and removing bottlenecks in key network infrastructures - Priority axis 7, connectivity and mobility is covered by the transport sector. Urban and regional mobility belongs to the investment priority $7 \mathrm{ii}$, which ensures funding of the drafting of strategic documents and project documentation and carrying out the projects (Table 1). 


\section{Table 1}

Priority axis 7. Connectivity and Mobility - Investment Priorities 7ii.

\begin{tabular}{|c|c|c|c|}
\hline Priority investments & Specific Objective & \multicolumn{2}{|c|}{ Cohesion funds $\left[10^{6} €\right]$} \\
\hline \multirow{3}{*}{$\begin{array}{l}\text { Investment priority 7ii } \\
\text { Developing and improving environmentally- } \\
\text { friendly (including low-noise level) and low- } \\
\text { carbon transport systems, including inland } \\
\text { waterways and maritime transport, ports, } \\
\text { multimodal links and airport infrastructure, } \\
\text { in order to promote sustainable regional and } \\
\text { local mobility }\end{array}$} & $\begin{array}{c}\text { Specific objective 7iil } \\
\text { Improving territorial cohesion and } \\
\text { connectivity and accessibility to the } \\
\text { islands }\end{array}$ & 80,00 & \multirow{3}{*}{370,00} \\
\hline & $\begin{array}{l}\text { Specific objective 7ii2 } \\
\text { Development of intelligent, sustainable } \\
\text { and integrated system of public transport } \\
\text { with low CO2 emissions }\end{array}$ & 170,00 & \\
\hline & $\begin{array}{c}\text { Specific objective } 7 \mathrm{ii} 3 \\
\text { Improvement of accessibility to } \\
\text { Dubrovnik by air }\end{array}$ & 120,00 & \\
\hline $\begin{array}{c}\text { Investment priority 7iii } \\
\text { Developing and rehabilitating comprehensive, } \\
\text { high quality and interoperable railway } \\
\text { systems, and promoting noise reduction } \\
\text { measures. }\end{array}$ & $\begin{array}{l}\text { Specific objective 7iiil } \\
\text { Increased capacity and use of public } \\
\text { transport and promotion of a modal shift }\end{array}$ & 480,21 & 480,21 \\
\hline
\end{tabular}

Source: (Ministry of the Economy, 2014)

So far the local and regional governments and self-governments and development agencies in the Republic of Croatia have received 43 mil. Croatian kuna (5.73 mil. €) from the European Regional Development Fund through the OP “Transport” 2017-2013 for drafting 10 Master plans of sustainable urban and suburban mobility (Figure 1) (Ministry of the Sea, Transport and Infrastructure, 2017) (Ministry of the Sea, Transport and Infrastructure. 2015.):

- Transport development master plan for the City of Osijek and Osijek-Baranja county;

- Development master plan for the traffic direction Rijeka (the City of Rijeka);

- A study of transport development of the Karlovac county;

- Intermodal urban eco-friendly bus and ferry public transport system - UrbEco (the City of Šibenik);

- Transport sustainable development master plan for the Brodsko-Posavska county;

- Transport master plan for the City of Vinkovci;

- Development of the functional region Southern Dalmatia (Dubrovnik-Neretva county);

- IPP and IPT Development Project for the regions of Northern Croatia (Varaždin county, KoprivnicaKriževci county, and Međimurje county);

- Sustainable mobility master plan for the region of the City of Zadar; and

- Phase 1 of the Transport system Master plan for the City of Zagreb, Zagreb county and Krapina-Zagorje county (analysis of the current situation and transport model development). 


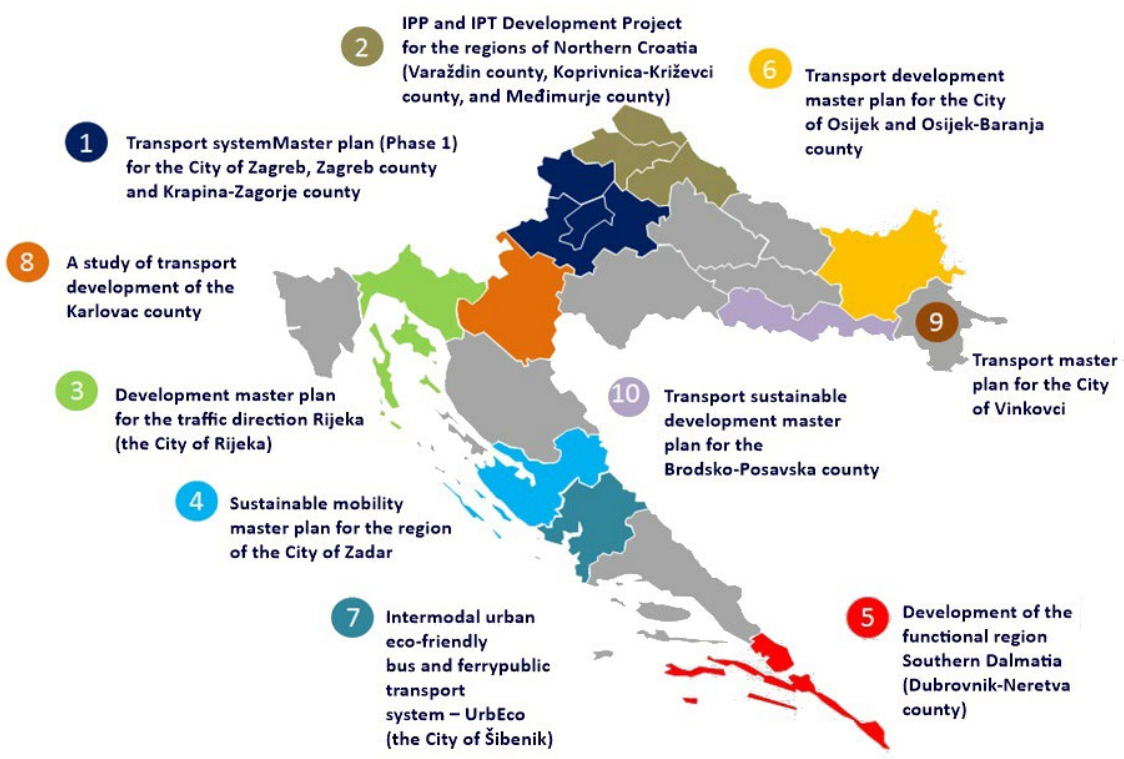

Fig. 1.

Sustainable Urban and Suburban Mobility Master Plans in the Republic of Croatia (Currently Being Drafted) Source: (Ministry of the Sea, Transport and Infrastructure, 2015)

Upon completion of all the plans, funding is possible for designing local plans of sustainable urban mobility and other documentation required to carry out projects through the OP "Competitiveness and Cohesion” (2014-2020).

The projects must be in accordance with the $\mathrm{OP}$ and include the following (Ministry of the Sea, Transport and Infrastructure, 2015):

- Infrastructure development and parking systems that are a continuation of the public transport;

- Procurement and modernisation of the passenger transport fleet with low $\mathrm{CO}_{2}$ emissions for the operators in the public transport;

- Application of surveillance system and intelligent transport system management within the urban areas;
- Introduction of common ticket system and modernised systems of notifying passengers; and

- Construction and improvement of cycling lanes.

\section{System of Integrated Passenger Transport and Shipping Tariff Union in the City of Zagreb, Zagreb County, and Krapina-Zagorje County}

Integrated passenger transport is a new system of public transport recognized and supported as being the optimal system of organising public transport in all the basic strategic documents (White paper, 2011). All the vehicles of public transport (trains, buses, trams, and others) comprise a unified system of passenger transport in a certain region. There are common (single) transport tickets for all the lines of public 
transport throughout the region. The system commonly uses timetables adjusted to regular time intervals. There is a large number of stations (terminals) for various vehicles in the public transport system. The railway acts as the axis of the system (trains, trams) due to its ecological and energetic benefits. The rest of the vehicles (buses) act as inflows to the railway.

End users, i.e. passengers profit the most from an integrated system, receiving transport connectivity with lines of the network of public transport, a common system of transport tickets, a common and simplified system of notifications about all the aspects of public transport, a common purchasing system, and a shorter journey times, and reduction in fares.

\subsection{The Realisation of Integrated Passenger Transport System Projects}

The transport systems of the City of Zagreb, Zagreb county and Krapina-Zagorje county have previously not been viewed as one entity, which resulted in unbalanced development of traffic infrastructure and management of transport processes, particularly in urban and suburban transport. This led to the fact that 60 per cent of journeys include personal vehicles. Consequently, there are many congestions, the traffic safety is lower, the noise level higher, there are harmful emissions, which ultimately affects the quality of life and competitiveness of region's economy. Improving mobility by relieving the traffic congestion, lowering the number of accidents and reducing pollution is a challenge for the cities and regions.

Transport projects demand cooperation and common efforts of more units of local government and regional self-government. This requires reaching a partnership agreement which would commit all the parties to adhere to the agreement in order to realise the project. In 2012, Agreement on integrated passenger transport and shipping tariff union for the City of Zagreb, Zagreb county and Krapina-Zagorje county was signed.

The agreement regulates the cooperation in the organisation, development and advancement of public urban and suburban transportation by means of setting up a system of integrated passenger transport and shipping tariff union in the area. The agreement was preceded by "Study on integrated passenger transport in the City of Zagreb, Zagreb county, and Krapina-Zagorje county" (City of Zagreb, 2008) carried out in 2008. The study proved that the proposed model of public transport organisation can be applied in the researched region.

With the partnership agreement all the requirements have been met to initiate the realisation of the IPTS project, defined in the Contract on phase 1 of the IPTS Project, which includes a design of two subprojects completed in 2014:

- Preliminary design of the IPTS organisation; and

- Preliminary design of the tariff system of the IPTS.

The model proposes that the urban and suburban railway in the greater Zagreb area, and the existing tram network in the centre of Zagreb, become the pillar of public passenger transport, until a construction of a newer and faster urban railway system. Urban and suburban bus 
connections would then complement the main railway lines.

In the new model of organisation of public passenger transport, railway systems should become carrier of traffic load, as an ecofriendly and sustainable system. According to the new concept of organisation of urbansuburban railway transport, urban and suburban trains would depart in regular time intervals (adjusted timetable).

Proposal for managing bus connections in the new organisation of public urban and suburban transport made for the model of the IPTS assumes significant undertakings in adapting the transport infrastructure to the IPTS, which mostly affects the organisation of intermodal junctions.

Figure 2 shows the preliminary design of the organisation of integrated passenger transport with intermodal junctions, existing and planned railway and tram lines between the junctions in the Zagreb area by the year 2025.

Phase II of Integrated passenger transport (IPTS) is comprised of projects and studies: (Integrated traffic of the Zagreb area, 2017)

- A study of adjustment of the operator's organisation structure to the modal of integrated passenger transport;

- Plan of transport infrastructure adjustment to the needs of the integrated passenger transport;

- Project of automation of tolls and ticket inspection in the integrated passenger transport system; and

- Project of notifying passengers - users of the integrated passenger transport.

\subsection{The Master Plan of the Transport System of the City of Zagreb, Zagreb County and Krapina-Zagorje County}

The undertaker of the Master plan is Integrated traffic of Zagreb area Ltd. (or "IPZP d.o.o."), founded with the objective of drafting and implementing projects related to the establishing and managing a new model of passenger transportation and management in the geographical area of the City of Zagreb, Zagreb County and Krapina-Zagorje County. Based on the initial investment by the City of Zagreb with a share of $60 \%$, Zagreb County with a share of $25 \%$ and Krapina-Zagorje with a share of $15 \%$, in 2016 the three parties signed a contract on the design of the Master plan for the transport system of the City of Zagreb, Zagreb County and Krapina-Zagorje County, to be carried out in two phases:

- Phase 1: Analysis of the current situation and development of the transport model. This phrase includes the collection of data on the current state of the transport system, which includes extensive traffic studies, counting, traffic surveys, data analysis and processing with the help of traffic model for the purpose of identifying problems and defining measures and actions to address them;

- Phase II: Development and selection of transport solutions by testing and evaluating various scenarios for development of the transport system and specific transport solutions, through appropriate, previously developed and adopted traffic model, defining priorities and stage development of the transport system, and carrying out Strategic Environmental Assessment. 

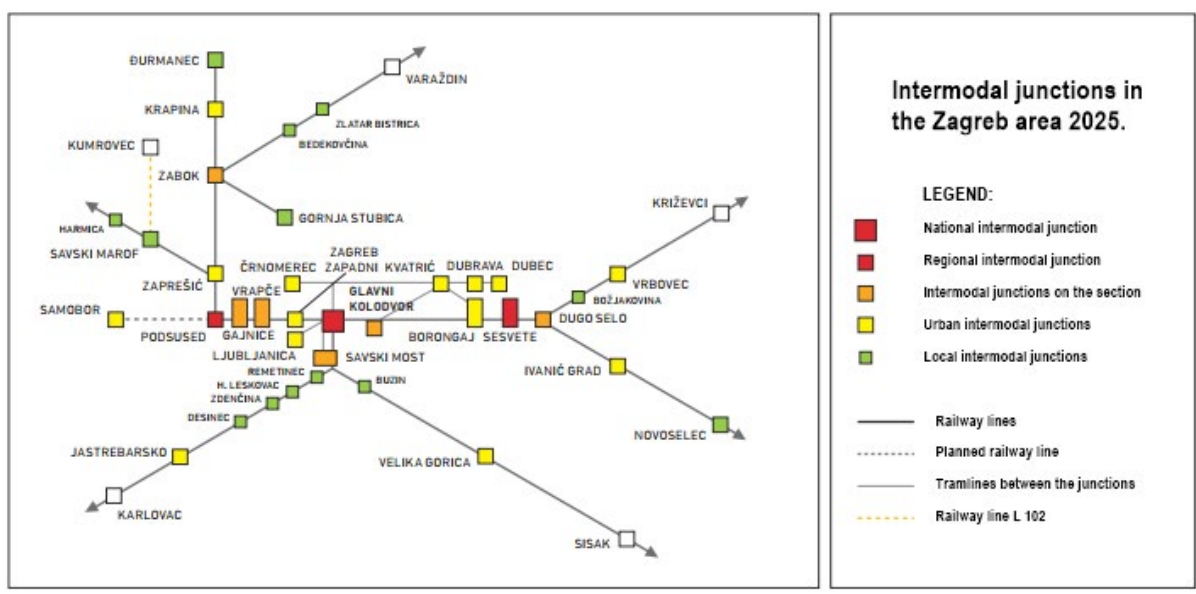

Fig. 2.

Preliminary Design of the Organisation of Integrated Passenger Transport

Source: (Integrated traffic of the Zagreb area, 2017)

Master plan will ensure the integration of transport subsystems through institutional, organisational and infrastructural improvements with emphasis on integrating systems of public urban and suburban transport. Implementing measures for the improvement of urban mobility is encouraged, as well as strengthening connectivity of the county with a city. An eco-friendly, energetically and economically acceptable urban transport is desired in the counties.

The concept and realisation of the Master plan through the project of integrated transport system will aid in improving accessibility to public transport, that is, the inclusion of neighbouring cities and regions into the integrated transport system of the City of Zagreb, through a common tariff. As a result of operational and organizational integration of all means of transport rail, tram and bus, as well as a variety of alternative forms of movement - there will be an increase in efficiency.
Using one ticket for a single trip in the area of integration would, in an integrated transport system, ensure higher quality and appeal of public transport services for passengers, as well as the shortened travel time, reduced cost of travel, and a better notification system.

With the help of the Master Plan, the following capital projects will be evaluated, which are either already planned to be implemented into the integrated transport system of the City of Zagreb, Zagreb County and Krapina-Zagorje County, or will be separate projects that will be supplement the integrated transport system project:

- The project of reconstruction of the Zagreb railway junction, including the de-levelling of railway line through the centre of Zagreb, the construction of the double-track railway towards suburban destinations: Velika Gorica, Samobor, Jastrebarsko, construction of freight bypass and the construction 
of Zagreb - Zagreb Airport - Velika Gorica connection, modernization and electrification of the Zaprešić - Zabok railway, reconstruction of Zabok Đurmanec - State border railway, and the reconstruction of the Savski Marof - Kumrovec - State border railway;

- Project of bus stops arrangement in the Krapina-Zagorje County;

- Project of central automated traffic management of the City of Zagreb;

- Project to construct fast, underground or over-ground rail system, such as a metro or light rail transit;

- Project to design a new Sljeme cable car;

- Project of the new road bypass around the City of Zagreb;

- Project of reconstruction and upgrade of the road distribution ring around the central part of the City of Zagreb;

- Project of central distribution station for road freight traffic of City of Zagreb;

- Project of reconstruction and upgrade of the tram network in the City of Zagreb;

- Project to construct a third lane of Karlovac-Zagreb motorway;

- Project to construct a railway from Podsused (factory) to Samobor-Bregana and others.

\section{Conclusion}

The general objective of the transport development of the Republic of Croatia is a balanced and sustainable transport system based on the principles of territorial cohesion. The Transport Development Strategy of the Republic of Croatia for 2014-2030 introduces the requirement of transport planning founded on a completely new bases, taking into consideration not only the infrastructural, but also operational and organisational aspects. Cooperation in a functional regional context is encouraged.
Cities and regions are expected to develop their own master plans as strategic documents for further development of transport projects and their funding from the EU.

The Transport operational programme 20172013 in the Republic of Croatia ensured cofunding of the design and undertaking of 10 master plans of sustainable urban and suburban mobility.

Agreement on integrated transport and the shipping tariff in the area of the City of Zagreb, Zagreb County and KrapinaZagorje was signed in 2012. The agreement stimulates implementing the measures for improving urban mobility, and strengthening connectivity of the counties with the City of Zagreb. Emphasis is placed on the needs of the local residents in their daily commutes, so that they would be guaranteed, through projects of integrated transport, a more accessible, faster, and affordable public transport. An eco-friendly, energetically and economically acceptable urban transport is promoted. A model, in which the urban and suburban railway would assume the main role in the public passenger transport in the greater Zagreb area, and the tram network in the narrow area of the City of Zagreb, is suggested. In such an organisation, urban and suburban bus lines would have to transit to the railway network.

Phase I of the Master plan of the transport system for the City of Zagreb, Zagreb county and Krapina-Zagorje county is currently being drafted, which would ensure integrating transport subsystems through institutional, organisational and infrastructural improvements with emphasis on integrating systems of public urban and suburban transport. 


\section{Acknowledgements}

The paper is supported by the PROM $\mathrm{PRO}$ research project „Adapting the railway system in the integrated passenger transport (ARSIPT) “, that is solved at Faculty of Transport and Traffic Sciences, University of Zagreb.

\section{References}

European Commission. 2011. Territorial Agenda of the European Union 2020. Brussels, Belgium. 11 p.

European Commission. 2011. White paper. Brussels, Belgium. $31 \mathrm{p}$.

European Commission. 2014. EU Cohesion Policy for 2014-2020. Brussels, Belgium. 8 p.

Gašparík, J.; Stopka, O.; Pečený, L. 2015. Quality Evaluation in Regional Passenger Rail Transport, Naše More 62(3): 114-118.

City of Zagreb. 2008. Study on integrated passenger transport in the City of Zagreb, Zagreb county, and Krapina-Zagorje county (Studija integriranog prijevoza putnika na području Grada Zagreba, Zagrebačke županije i Krapinsko-Zagorske županije; In Croatian). Croatia. 57 p. Available from internet: <http://www.szz.hr/wpcontent/uploads/2011/01/sazetak-studijaidshr.pdf >

Croatian Chamber of Economy. 2015. Cohesion Policy of the European Union and Croatia (Kohezijska politika Europske unije i Hrvatska 2014. - 2020.; In Croatian). Zagreb, Croatia. 72 p. Available from internet: <https://izvoz.gov.hr/UserDocsImages/dokumenti/ Kohezijska\%20politika\%20EU\%20i\%20Hrvatska\%20 2014.-2020..pdf>

Integrated traffic of the Zagreb area. 2017. Integrated passenger public transport (Integrirani prijevoz putnika; In Croatian). Available from Internet: <http://www. ipzp.hr/integrirani-prijevoz-putnika-ipp/>
Ministry of the Economy. 2014. Operational Programme Competitiveness and Cohesion 2014 2020 2014HR16M1OP001-1.2. Zagreb, Croatia. 316 p. Available from internet: <https://www.mingo.hr/ public/investicije/OPKK_2014_2020_31316.pdf>

Ministry of the Sea, Transport and Infrastructure. 2015. Preparing project of sustainable urban and regional mobility for financing from EU funds. (Priprema projekata održive urbane i regionalne mobilnosti za financiranje iz EU fondova; In Croatian). Zagreb, Croatia. 16 p. Available from internet: <http://www.promet-eufondovi.hr/ UserDocsImages/Strategy/UPUTA_Priprema projekata urbane i regionalne mobilnosti za financiranje iz EU fondova_MPPI_03\%202015.pdf>

Ministry of the Sea, Transport and Infrastructure. 2015. Workshop Sustainable urban mobility plans. Koprivnica, Croatia. 25 p. Available from internet: <http://www. eltis.org/sites/eltis/files/presentation_2_sump_in_ croatia_petra_petra_grgasovic.pdf $>$

Ministry of the Sea, Transport and Infrastructure. 2017. Transport development strategy of the Republic of Croatia 2017 - 2030. 154 p. Available from internet: <http://www.mppi.hr/default.aspx?id=16279>

Official Gazette of the Republic of Croatia. 2015. Environmental Protection Law (Zakon o zaštiti okoliša; In Croatian). Available from internet: <http://narodnenovine.nn.hr/clanci/sluzbeni/2015_07_78_1498.html>

Šimecki, A.; Steiner, S.; Čokorilo, O. 2013. The Accessibility Assessment of Regional Transport Network in the South East Europe, International Journal for Traffic and Transport Engineering 3(4): 351 - 364.

Stopka, O.; Bartuška, L.; Kampf, R. 2015. Passengers' Evaluation of the Integrated Transport Systems, Naše more 62(3): 153-157.

Stoilova, S.; Nikolova, R. 2016. Classifying Railway Passenger Stations for use Transport Planning-Application to Bulgarian Railway Network, Transport Problems 11(2): 143-155. 
Torok, A. 2016. Assessment of Regional Transport with Map Deformation: A Case Study for Budapest, Procedia Engineering 134: 4-8.

Van de Vijver, E.; Derudder, B.; Witlox, F. 2016. Air Passenger Transport and Regional Development: Cause and Effect in Europe, PROMET - Traffice Transportation 28(2): 143 - 154 .

Zitricky, V.; Gašparik, J.; Pečeny, L. 2015. The Methodology of Rating Quality Standards in the Regional Passenger Transport, Transport Problems 10(SE): 59-72. 